\title{
Homocysteine thiolactone inhibits insulin-stimulated DNA and protein synthesis: possible role of mitogen-activated protein kinase (MAPK), glycogen synthase kinase-3 (GSK-3) and p70 S6K phosphorylation
}

\author{
S Najib and V Sánchez-Margalet \\ Department of Medical Biochemistry and Molecular Biology, School of Medicine Investigation Unit, Virgen Macarena University Hospital, Av. Sanchez Pizjuan 4, Seville 41009, \\ Spain
}

(Requests for offprints should be addressed to V Sánchez-Margalet; Email: Margalet@us.es)

\begin{abstract}
Hyperhomocysteinemia and insulin resistance are independent factors for cardiovascular disease. Most of the angiotoxic effects of homocysteine are related to the formation of homocysteine thiolactone and the consequent increase in oxidative stress. We have recently found that homocysteine thiolactone inhibits insulin receptor tyrosine kinase activity, which results in decreased phosphatidylinositol 3-kinase (PI3K) activity and inhibition of glycogen synthesis. Oxidative stress seemed to be the mechanism underlying these effects, since glutathione was able to restore the insulin signaling as well as the insulin-mediated glycogen synthesis. In the present work we have further investigated insulin receptor signaling studying mitogen-activated protein kinase (MAPK), glycogen synthase kinase-3 (GSK-3) and p70 S6K phosphorylation. Again, homocysteine thiolactone (50 $\mu \mathrm{M})$ prevented insulin-mediated MAPK, GSK-3 and p70 S6K phosphorylation and these effects were blocked by glutathione $(250 \mu \mathrm{M})$. Since MAPK and PI3K pathways, including GSK3 and S6K, seem to mediate insulin-mediated growth and proliferation, we measured DNA and protein synthesis. We have found that homocysteine thiolactone $(50 \mu \mathrm{M})$ inhibits insulin-mediated growth and proliferation, as previously shown for glycogen synthesis. Again, these effects seem to be mediated by oxidative stress, since $250 \mu \mathrm{M}$ glutathione completely abolished the effects of homocysteine thiolactone on insulin-stimulated DNA and protein synthesis. In conclusion, these data suggest that homocysteine thiolactone impairs insulin signaling by a mechanism involving oxidative stress, leading to a defect in the action of insulin on growth and proliferation.
\end{abstract}

Journal of Molecular Endocrinology (2005) 34, 119-126

\section{Introduction}

Elevated plasma levels of homocysteine are an independent risk factor for atherothrombosis (Boushey et al. 1995, Kang \& Wong 1996, McCully 1996). Hereditary enzymatic deficiencies and nutritional deficiencies of folate, pyridoxine or cobalamin - as well as chronic renal failure - are associated with elevated blood homocysteine and accelerated atherosclerosis (Guttormsen et al. 1996, Jacques et al. 1996, Kang \& Wong 1996, Robinson et al. 1996). The etiological factors for atherosclerosis are believed to increase conversion of methionine to homocysteine thiolactone, the reactive cyclic internal lactone of homocysteine (McCully 1993, Jakubowski et al. 2000). The synthesis of homocysteine thiolactone occurs in all human cell types and increased homocysteine levels lead to elevation of thiolactone levels in human cells (Jakubowski 1997). The oxidant stress of hyperhomocysteinemia, partly mediated by the production of thiolactone, seems to underly the vascular dysfunction produced by homocysteine (Blundel et al. 1996, Loscalzo 1996).
Another independent risk factor for atherosclerosis is insulin resistance (Ferrannini et al. 1991, Reaven 1993), and oxidative stress is supposed to be a causal link (Ceriello \& Pirisi 1995, Paolisso \& Giuliano 1996, Wittmann \& Nagy 1996,). Thus, oxidative stress has been shown to reduce insulin action in vivo (NouroozZadeh et al. 1997, De Mattia et al. 1998) and in vitro (Rudich et al. 1997, Blair et al. 1999, Khamaisi et al. 2000), as well as insulin signaling (Blair et al. 1999, Hansen et al. 1999, Tirosh et al. 1999). Moreover, homocysteine may have a link with insulin resistance; we have previously found that hyperhomocysteinemia is associated with hyperinsulinemia in an oral glucose tolerance test in obese subjects (Sánchez-Margalet et al. 2002), and increased plasma homocysteine levels have been observed in the insulin-resistance syndrome (Meigs et al. 2001), in patients with polycystic ovary syndrome associated with insulin resistance (Schachter et al. 2003) and in women with gestational diabetes mellitus (Seghieri et al. 2003). In this context, hyperhomocysteinemia has been proposed as a component of syndrome X (Oron-Herman et al. 2003). Oxidative stress 
is supposed to mediate the effects of homocysteine on atherosclerosis; however, little is known about the possible effect of homocysteine on insulin signaling. We have recently found that homocysteine thiolactone inhibits insulin signaling in hepatoma cells (HTC) overexpressing human insulin receptors (HTG-IR) (Najib \& Sánchez-Margalet 2001), thereby providing some molecular mechanism for the insulin resistance induced by homocysteine. We also found that glutathione had a protective effect on this inhibition. Therefore, we proposed the hypothesis that, in vitro, homocysteine thiolactone could inhibit insulin signaling by inducing oxidative stress (Najib \& Sánchez-Margalet 2001).

Insulin is known to activate multiple signaling pathways (Cheatham \& Kahn 1995, Myers \& White 1996, Avruch 1998), but the early events are the activation of tyrosine kinase activity of the insulin receptor $\beta$-subunit (White et al. 1988), the tyrosine phosphorylation of its substrates (Sun et al. 1992, Sung et al. 1994, Sánchez-Margalet \& Najib 1999) and the interaction with Src homology domain 2 (SH2)-domaincontaining proteins, such as p85, the regulatory subunit of phosphatidylinositol 3-kinase (PI3K) (Sun et al. 1992, Sánchez-Margalet et al. 1995, Sánchez-Margalet \& Najib 1999), or Grb2, which mediates the activation of the Ras-MAPK (mitogen-activated protein kinase) pathway (Skolnik et al. 1993). PI3K plays a central role in regulating glucose transport and glycogen synthesis (Sánchez-Margalet et al. 1994, Sánchez-Margalet 2000). PI3K pathways can inhibit glycogen synthase kinase-3 (GSK-3) by promoting its phosphorylation (Cross et al. 1994, 1995), which results in activation of glycogen synthase. The PI3K pathway also activates p70 S6K, which also mediates glycogen synthesis (Sánchez-Margalet 2000) as well as DNA and protein synthesis (Dixon et al. 1999, Vinals et al. 1999).

In previous studies we have shown that short-term incubation with homocysteine thiolactone inhibits the early steps of insulin receptor signaling - i.e. tyrosine phosphorylation, protein-protein interaction and PI3K activity - resulting in inhibition of insulin-stimulated glycogen synthesis.

In the present paper we have investigated the insulin receptor signaling pathways downstream of PI3K, by studying phosphorylation levels of GSK-3 and p70 S6K; these not only control glycogen synthesis, but also cell proliferation via accumulation of cytoplasmic $\beta$-catenin (Nakamura 1997, Gui et al. 1998) and activation of translation machinery (Dixon et al. 1999, Vinals et al. 1999) respectively. We have also investigated the effect of homocysteine thiolactone on another insulinstimulated mitogenic pathway, MAPK (Ahn et al. 1993, Van Obberghen et al. 1993, Cheatham \& Kahn 1995, Avruch 1998). Finally, we have studied the inhibitory effect of homocysteine thiolactone on insulin-stimulated growth and proliferation in HTC hepatoma cells.

\section{Materials and methods}

\section{Materials}

Polyclonal antibodies to phosphorylated GSK-3, which recognize GSK-3 $\alpha$ phosphorylated at serine 21 and GSK-3 $\beta$ phosphorylated at serine 9, and polyclonal antibodies to phosphorylated p70 S6 kinase (Thr421/ Ser424) were obtained from Cell Signaling New England Biolabs (Beverly, MA, USA). Monoclonal antibodies that recognize GSK- $3 \alpha$ and GSK-3 $\beta$, and p70 SK were from Santa Cruz Biotechnology (Santa Cruz, CA, USA). Polyclonal antibodies to phosphorylated p44/42-MAPK (Thr202/Thr204) and monoclonal antibodies that recognize p44/42-MAPK were from New England Biolabs.

\section{Methods}

Cells

Rat HTC-IR hepatoma cells were kindly provided by Dr I D Goldfine (UCSF, San Francisco, CA, USA). Cells were prepared and maintained in Dulbecco's modified Eagle's medium (DMEM; $1 \mathrm{~g} / \mathrm{l}$ glucose) as described previously (Sung et al. 1995). For signaling experiments, cells were grown in $100 \mathrm{~mm}$ dishes to $90 \%$ confluency and were serum-starved for $24 \mathrm{~h}$. They were treated for $10 \mathrm{~min}$ at $37^{\circ} \mathrm{C}$ with $100 \mathrm{nM}$ insulin, and preincubated or not with $50 \mu \mathrm{M}$ homocysteine thiolactone for $10 \mathrm{~min}$ prior to insulin stimulation. The insulin concentration used is the dose achieving maximal effects in insulin receptor signaling (Sung et al. 1994). The concentration of homocysteine thiolactone used in the experiments was the lowest concentration to achieve maximal inhibition of insulin receptor activation (Najib \& Sánchez-Margalet 2001) and is a concentration that can be achieved in intermediate hyperhomocysteinemia $(15-50 \mu \mathrm{M})$. In some experiments, $250 \mu \mathrm{M}$ glutathione was added $5 \mathrm{~min}$ before homocysteine thiolactone preincubation. This concentration of glutathione was previously found to prevent the inhibitory effect of homocysteine in insulin receptor activation (Najib \& Sánchez-Margalet 2001). Homocysteine and glutathione were not washed before insulin stimulation, and were present during the incubation time. Cells were solubilized for $30 \mathrm{~min}$ at $4{ }^{\circ} \mathrm{C}$ in lysis buffer containing: $20 \mathrm{mM}$ Tris, $\mathrm{pH} \mathrm{8,1 \%}$ Nonidet P-40, $137 \mathrm{mM} \mathrm{NaCl}$, $1 \mathrm{mM} \quad \mathrm{MgCl}_{2}, \quad 1 \mathrm{mM} \quad \mathrm{CaCl}_{2}, 1 \mathrm{mM}$ dithiothreitol (DTT), 10\% glycerol, $1 \mathrm{mM}$ phenylmethylsulfonyl fluoride and $0.4 \mathrm{mM}$ sodium orthovanadate (SánchezMargalet et al. 1995). After centrifugation, the soluble cell lysates were used for the study. For insulin-action experiments, cells were grown in six-well plates to $90 \%$ confluence and were serum-starved for $16 \mathrm{~h}$. 


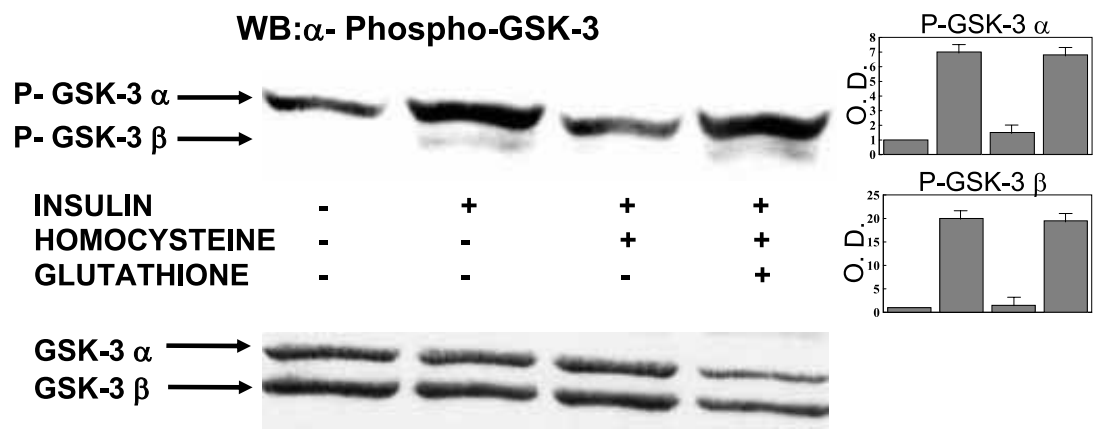

WB: $\alpha$-GSK-3

Figure 1 Effect of homocysteine thiolactone on insulin-mediated phosphorylation of GSK-3. Serum-starved HTC-IR cells were pretreated with or without $50 \mu \mathrm{M}$ homocysteine thiolactone for 10 min before stimulation with or without $100 \mathrm{nM}$ insulin for $10 \mathrm{~min}$. When employed, glutathione $(250 \mu \mathrm{M})$ was added 5 min before homocysteine. Cell lysates were subjected to SDS-PAGE and analysed by western blotting with antibodies that recognize GSK-3 phosphorylated at serine 21 (GSK-3 $\alpha$ ) and 9 (GSK-3 $\beta$ ). Cell lysates were also analysed by immunoblot with anti-GSK-3.

Blots are representative experiments out of four.

\section{Phosphorylation of GSK-3, p70 S6K and MAPK}

Activation or inactivation of GSK-3, p70 S6K and MAPK were evaluated by the phosphorylation status, employing antibodies that specifically recognize the phosphorylated form of the proteins (New England BioLabs).

Cells were solubilized for $30 \mathrm{~min}$ at $4{ }^{\circ} \mathrm{C}$ in lysis buffer as previously described (Sung et al. 1994). Protein concentration was determined using the Micro BCA protein assay kit from Pierce (Rockfold, IL, USA). Samples were denatured and resolved by SDS-PAGE, transferred onto nitrocellulose membranes and analyzed by immunoblot using the appropriate antibodies as previously described (Sung et al. 1994, Sánchez-Margalet \& Najib 1999) using a highly sensitive chemiluminescence system (Supersignal, Pierce). The amount of GSK-3, p70 S6K and p42/44 MAPK in each lane was controlled by immunoblot with the corresponding antibodies, which were employed to normalize the results. The bands obtained were scanned and analyzed using the PCBAS2.0 program (Raytest Isotopenmessgeräte, Straubenhardt, Germany).

\section{[3H]Thymidine incorporation into DNA}

Cells were treated for $6 \mathrm{~h}$ with different stimuli. Next, $\left[{ }^{3} \mathrm{H}\right]$ thymidine $(0.5 \mu \mathrm{Ci} /$ well $)$ was added and incubation continued for $4 \mathrm{~h}$. Cells were washed with PBS and solubilized in $0.03 \%$ SDS, precipitated with $10 \%$ trichloroacetic acid (TCA) and radioactivity measured by a liquid scintillation counter as previously described (Sánchez-Margalet et al. 1994).

\section{$\left[{ }^{3} H\right]$ Leucine incorporation into protein}

Cells were treated for $3 \mathrm{~h}$ with or without different stimuli. Next, L-[2,3,4,5- $\left.{ }^{3} \mathrm{H}\right]$ leucine $(0 \cdot 5 \mu \mathrm{Ci} /$ well $)$ was added and incubation continued for $2 \mathrm{~h}$. Cells were then washed and solubilized in $0.03 \%$ SDS. Samples were then TCA precipitated and counted as described previously (Sánchez-Margalet et al. 1994).

\section{Statistical analysis}

Values presented are means \pm S.E.M. The statistical study was performed by ANOVA and Student's $t$-test for paired data; Bonferroni post-hoc test was used to compare values from different concentration points. Differences were considered significant when $P<0 \cdot 05$.

\section{Results}

\section{Homocysteine thiolactone inhibits insulin-stimulated GSK-3 and p70 S6K phosphorylation}

To examine the effect of homocysteine thiolactone on insulin-stimulated GSK-3 inhibition, we studied the phosphorylation level of GSK-3 using specific antibodies that recognize GSK-3 phosphorylated at serine 21 (GSK-3 $\alpha$ ) and 9 (GSK-3 $\beta$ ). GSK-3 is one of the known targets of protein kinase $\mathrm{B}(\mathrm{PKB})$, and is the mechanism whereby insulin inactivates this enzyme (van Weeren et al. 1998). Serum-starved HTC-IR cells were preincubated with $50 \mu \mathrm{M}$ homocysteine thiolactone for $10 \mathrm{~min}$ prior to stimulation for $10 \mathrm{~min}$ with $100 \mathrm{nM}$ insulin. Cell lysates were subjected to SDS-PAGE and were analysed by western blotting with antibodies against the phosphorylated forms of GSK-3. As shown in Fig. 1, insulin-mediated phosphorylation of both isoforms, GSK- $\alpha$ and GSK- $\beta$, was prevented by preincubation with homocysteine thiolactone. We next investigated the possible role of oxidative stress in the inhibitory effect 


\section{WB: $\alpha-$ Phospho-S6K}
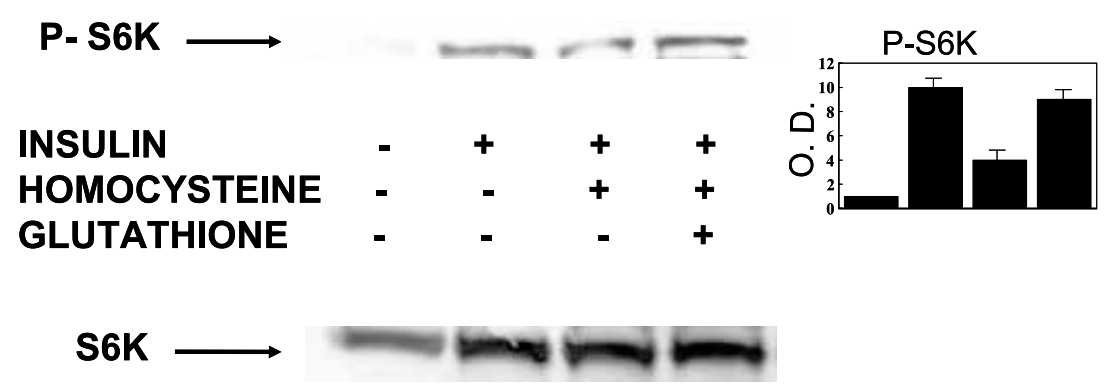

\section{WB: $\alpha-S 6 K$}

Figure 2 Effect of homocysteine thiolactone on insulin-mediated phosphorylation of S6K. Cells were treated as described in the legend for Fig. 1. Cell lysates were subjected to SDS-PAGE and analysed by immunoblot with anti-phospho-S6K. Results are representative of three experiments.

of homocysteine thiolactone. Thus, we added $250 \mu \mathrm{M}$ glutathione 5 min before the preincubation of HTG-IR cells with homocysteine thiolactone. As shown in Fig. 1, glutathione restored the insulin-mediated phosphorylation of both isoforms (GSK-3 $\alpha$ and GSK-3 $\beta$ ).

Downstream of PI3K and 3-phosphoinositidedependent protein kinase (PDK) in insulin receptor signaling, p70 $\mathrm{S} 6 \mathrm{~K}$ is also activated. Since p70 S6K activity is correlated with its phosphorylation state, specifically Thr421 and Ser424 (Alessi et al. 1998, Pullen et al. 1998), we employed polyclonal antibodies that detect p70 S6K only when phosphorylated at Thr421/Ser424. Therefore, we analyzed the same cell lysates used in Fig. 1 by immunoblot with anti-phospho-S6K antibodies. As shown in Fig. 2, we observed results parallel to those of GSK-3. Thus, insulin stimulated the phosphorylation of $\mathrm{p} 70 \mathrm{~S} 6 \mathrm{~K}$, and this effect was inhibited by preincubation with homocysteine thiolactone. Again, preincubation of cells with $250 \mu \mathrm{M}$ glutathione prevented the inhibitory effect of homocysteine thiolactone on insulin-mediated p70 S6K phosphorylation.

\section{Homocysteine thiolactone inhibits insulin-mediated activation of the MAPK pathway}

In order to explore the MAPK pathway, we investigated the threonine phosphorylation level of MAPK (Thr202/ Thr204) because MAPK kinase (MEK), the upstream kinase, is known to activate MAPK through phosphorylation of threonine and tyrosine residues (Payne et al. 1991), which is the mechanism of activation in response to insulin. Thus, we employed antibodies that specifically recognize the phosphorylated form of p44/42 MAPK to assess the activation of this pathway. As shown in Fig. 3, insulin strongly stimulated the phosphorylation of both p44 and p42 MAPK. However, when cells were preincubated for $10 \mathrm{~min}$ in the presence of $50 \mu \mathrm{M}$ homocysteine thiolactone, before insulin stimulation, the effect was abolished. We also wanted to investigate the possible role of oxidative stress in the homocysteine inhibition of the insulin-stimulated MAPK pathway. Thus, we added $250 \mathrm{mM}$ glutathione $5 \mathrm{~min}$ before the preincubation with homocysteine thiolactone, and the effect of insulin on p44/42 MAPK phosphorylation was restored (Fig. 3).

\section{Homocysteine thiolactone inhibits insulin-mediated stimulation of growth and proliferation}

Since GSK-3, S6K and MAPK pathways regulate growth and proliferation, we investigated the effect of homocysteine in these insulin-mediated effects. As shown in Fig. 4, $50 \mu \mathrm{M}$ homocysteine thiolactone completely blocked the mitogenic effect of insulin in HTC-IR hepatoma cells. This inhibitory effect of homocysteine thiolactone was fully prevented by the preincubation of cells with glutathione $(250 \mu \mathrm{M})$ prior to the addition of homocysteine, suggesting a possible role of oxidative stress in the inhibitory effect of homocysteine.

We also studied the effect of homocysteine on insulin-stimulated protein synthesis. As shown in Fig. 5, $50 \mu \mathrm{M}$ homocysteine thiolactone completely blocked the effect of insulin stimulating protein synthesis in HTG-IR hepatoma cells. Again, this inhibitory effect of homocysteine thiolactone was fully prevented by the preincubation of cells with glutathione $(250 \mu \mathrm{M})$ prior to the addition of homocysteine.

\section{Discussion}

We have recently found that homocysteine thiolactone inhibits insulin receptor tyrosine kinase, phosphorylation 


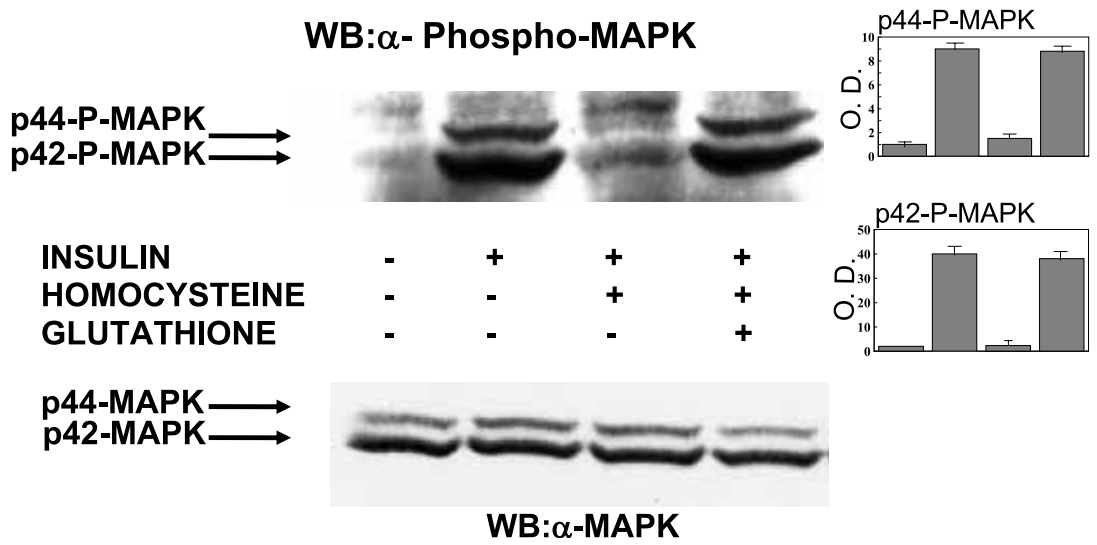

Figure 3 Effect of homocysteine thiolactone on insulin-mediated p42/44 MAPK phosphorylation. Cells were treated as described in the legend for Fig. 1. When employed, glutathione $(250 \mu \mathrm{M})$ was added 5 min before homocysteine. Cell lysates were subjected to SDS-PAGE and analysed by western blotting with anti-phospho-MAPK. Cell lysates were also analysed by western blotting with anti-MAPK antibody. Blots are representative experiments out of four.

of insulin receptor substrates and insulin-stimulated PI3K activity, leading to an inhibitory effect on insulinmediated glycogen synthesis in HTC hepatoma cells overexpressing human insulin receptor (HTC-IR) (Najib \& Sánchez-Margalet 2001). In the present study we demonstrate that short-term treatment of HTG-IR cells with micromolar concentrations of homocysteine thiolactone $(50 \mu \mathrm{M})$ also inhibits mitogenic insulin

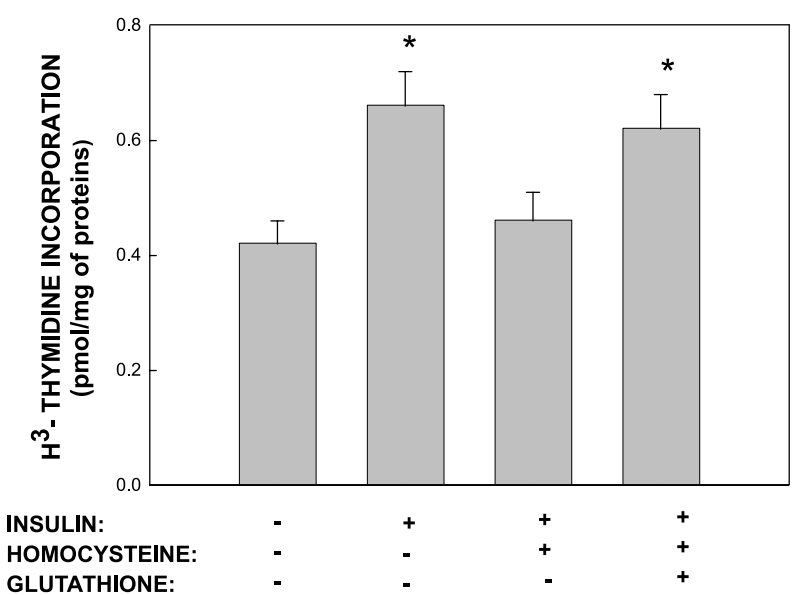

Figure 4 Homocysteine thiolactone inhibits DNA synthesis and the protective effect of glutathione. Cells were treated as described in the legend for Fig. 1, but insulin (100 nM) stimulation was extended for $6 \mathrm{~h}$. Next, $\left[{ }^{3} \mathrm{H}\right]$ thymidine $(0.5 \mu \mathrm{Ci} /$ well $)$ was added and incubation continued for $4 \mathrm{~h}$. Cells were washed with PBS and solubilized in $0.03 \%$ SDS, precipitated with $10 \%$ TCA and radioactivity was measured by a liquid scintillation counter. When employed, glutathione $(250 \mu \mathrm{M})$ was added $5 \mathrm{~min}$ before homocysteine. Data are means \pm S.E.M. of four separate experiments. ${ }^{*} P<0.05$ compared with basal. signaling and action, leading to an inhibitory effect on insulin-stimulated DNA and protein synthesis.

First, we present data showing homocysteine inhibition of insulin-stimulated mitotic signaling pathways GSK-3, p70 S6K and MAPK - which are known to mediate signals of cell growth and proliferation (Plyte et al. 1992, Ahn et al. 1993, Van Obberghen et al. 1993, Cheatham \& Kahn 1995, Avruch 1998, Cui et al. 1998,

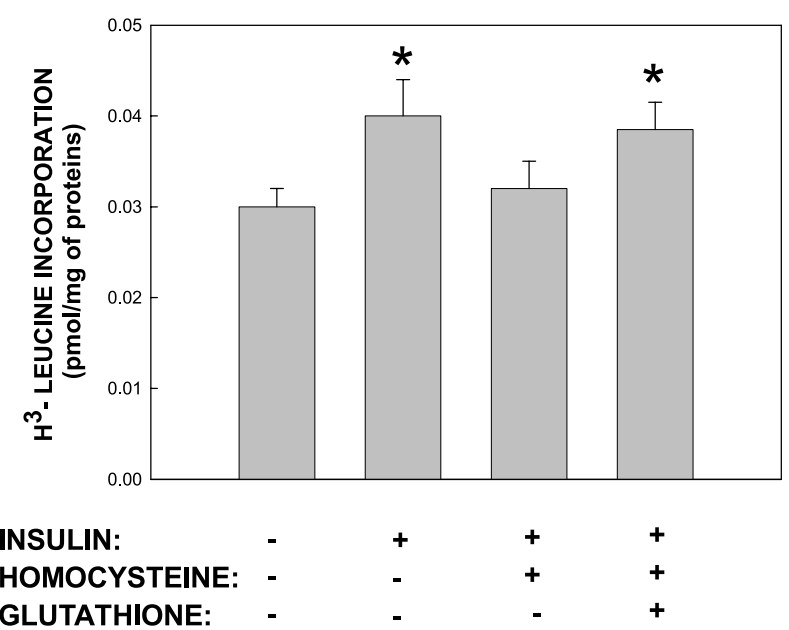

Figure 5 Homocysteine thiolactone inhibits protein synthesis and the protective effect of glutathione. Cells were treated as described in the legend for Fig. 1, but insulin (100 nM)

stimulation was extended for $3 \mathrm{~h}$, and then $\left[{ }^{3} \mathrm{H}\right]$ leucine $(0.5 \mu \mathrm{Ci})$ was added and incubation continued for $2 \mathrm{~h}$. Cells were then washed, solubilized and TCA precipitated. Radioactivity was finally measured by a liquid scintillation counter. When employed, glutathione $(250 \mu \mathrm{M})$ was added 5 min before homocysteine. Data are means \pm S.E.M. of four separate experiments performed in triplicate. ${ }^{\star} P<0.05$ compared with basal. 
Dixon et al. 1999, Vinals et al. 1999). Since we have previously observed the inhibitory effect of homocysteine thiolactone in early events of insulin receptor signaling i.e. the tyrosine phosphorylation of substrates and the interaction with p85 PI3K and PI3K activity (Najib \& Sánchez-Margalet 2001) - the inhibition of GSK-3 phosphorylation may be secondary to the inhibition of the PI3K pathway because GSK-3 is a target of PKB (Cross et al. 1995), which is downstream of PI3K (Cheatham \& Kahn 1995, Sánchez-Margalet 2000). In fact, the inhibition of GSK-3 phosphorylation by homocysteine may also explain the inhibitory effect on insulin-mediated glycogen synthesis previously observed in HTC-IR cells (Najib \& Sánchez-Margalet 2001). However, GSK-3 phosphorylates a broad range of substrates in addition to glycogen synthase, including important growth regulators such as $\beta$-catenin (Ikeda et al. 1998), cyclin D1 (Diehl et al. 1998), or p21 (Rossig et al. 2002), as well as numerous transcription factors (Manoukian \& Woodgett 2002). Therefore the effect of homocysteine thiolactone inhibiting growth and proliferation may be partially mediated by preventing GSK-3 phosphorylation. In support of this, insulin-stimulated PKB activity has been previously found to be prevented by oxidative stress (Pham et al. 2000). Moreover, the PI3K pathway also mediates the activation of p70 S6K, by phosphorylation via PDK or mammalian target of rapamycin (mTOR) (Sehgal 1995, Alessi et al. 1998, Pullen et al. 1998). mTOR and S6K may also mediate insulin-stimulated glycogen synthesis (Sánchez-Margalet 2000), as well as DNA and protein synthesis (Dixon et al. 1999, Vinals et al. 1999). Therefore, inhibition by homocysteine thiolactone of insulin-mediated p70 S6K may partly mediate the inhibitory effect of homocysteine on glycogen synthesis in these cells (Najib \& SánchezMargalet 2001), as well as the inhibition of protein synthesis that we have observed in the present work.

On the other hand, we have previously observed homocysteine inhibition in the tyrosine phosphorylation of insulin receptor substrates, resulting in the inhibition of their interaction with p85 PI3K (Najib \& SánchezMargalet 2001). Similarly, the inhibition of tyrosine phosphorylation may also impair their interaction with Grb2-SOS, inhibiting the Ras signaling pathway. In this way, homocysteine thiolactone incubation may finally lead to the inhibition of MAPK, as we have assessed in the present work. However, we have not checked the effects on the early steps of the MAPK pathway.

However, we do not know whether other effects on the MAPK pathway, such as the activation of MAPK phosphatases (MKP), may be contributing to the inhibition of MAPK phosphorylation (Bhalla et al. 2002). In this context, oxidative stress is known to induce the expression and activity of MKP-1 (Akhand et al. 2001, $\mathrm{Xu}$ et al. 2004). Since the homocysteine inhibition of MAPK phosphorylation is reversed by glutathione, part of the effect could be mediated by the oxidative stress on some MKP. The effect of homocysteine would be more likely to be due to the regulation of the activity, rather than the induction of expression, because it is observed in short-term incubation. This is a speculation that may be worth investigating, however. In any case, the homocysteine inhibition of the tyrosine phosphorylation of insulin receptor substrates may be sufficient for the impairment of the MAPK pathway, since it depends on tyrosine kinase activity (Lipson et al. 1998).

The inhibitory effect of oxidative stress on insulin signaling has been studied previously (Blair et al. 1999, Hansen et al. 1999, Tirosh et al. 1999, Najib \& Sánchez-Margalet 2001), as well as the inhibition of insulin action by oxidative stress or the inhibition of glutathione synthesis (Rudich et al. 1997, Blair et al. 1999, Khamaisi et al. 2000, Najib \& Sánchez-Margalet 2001). Regarding the action of insulin on DNA synthesis and proliferation, oxidative stress has been demonstrated to inhibit this specific insulin effect (Orzechowski et al. 2002), which is restored with anti-oxidant agents. Similarly, other groups have shown that oxidative stress also prevents insulin-stimulated protein synthesis by inhibiting PKB and 4 EBP1 (Pham et al. 2000). Our data show homocysteine inhibition of insulin-mediated GSK, p70 S6K and MAPK pathways - resulting in an impairment in insulin action, i.e. growth and proliferation - by a mechanism mediated by oxidative stress; therefore, our data are consistent with previous work by other groups and provide new evidence to support the hypothesis of oxidative stress as a cause of insulin resistance. In this context, the inhibition of insulin signaling and insulin action could be another oxidationmediated toxic effect of homocysteine on liver cells, in addition to the reported toxic effects in endothelial cells in culture (de Groot et al. 1983, Starkebaum \& Harlam 1986, Stamler et al. 1993). Therefore, our results further implicate homocysteine in the pathophysiology of oxidative stress and point to a possible role of homocysteine in insulin resistance.

\section{Funding}

This work was supported by the Consejería de Salud, Junta de Andalucia, Spain (grant 05/02). S N is the recipient of a fellowship from Virgen Macarena University Hospital (Beca Asociacion Sanitaria).

\section{References}

Ahkand AA, Hossain K, Kato M, Miyata T, Du J, Suzuki H, Kurokawa K \& Nakashima I 2001 Glyoxal and methylglyoxal induce aggregation and inactivation of ERK in human endothelial cells. Free Radical Biology and Medicine 31 1228-1235. 
Ahn NG, Seger R \& Krebs EG 1993 The mitogen-activated protein kinase activator. Current Opinion in Cell Biology 4 992-999.

Alessi DR, Kozlowski MT, Weng QP, Morrice N \& Avruch J 1998 3-Phosphoinositide-dependent protein kinase 1 (PDK1) phosphorylates and activates the p70 S6 kinase in vivo and in vitro. Current Biology 8 69-81.

Avruch J 1998 Insulin signal transduction through protein kinase cascades. Molecular and Cell Biochemistry 182 31-48.

Bhalla US, Ram PT \& Iyengar R 2002 MAP kinase phosphatase as a locus of flexibility in a mitogen-activated protein kinase signaling network. Science 297 1018-1023.

Blair AS, Hajduch E, Litherland GJ \& Hundal HS 1999 Regulation of glucose transport and glycogen synthesis in L6 muscle cells during oxidative stress. Evidence for cross-talk between the insulin and SAPK2/p38 mitogen-activated protein kinase signaling pathways. Fournal of Biological Chemistry 274 36293-36299.

Blundell G, Jones BG, Rose FA \& Tudball N 1996 Homocysteine mediated endothelial cell toxicity and its amelioration. Atherosclerosis 122 163-172.

Boushey CJ, Beresford SA, Omen GS \& Motulsky AG 1995 A quantitative assessment of plasma homocysteine as a risk factor for vascular disease. Probable benefits of increasing folic acid intakes. Fournal of the American Medical Association 274 1049-1057.

Ceriello A \& Pirisi M 1995 Is oxidative stress the missing link between insulin resistance and atherosclerosis? Diabetologia 38 1484-1485.

Cheatham B \& Kahn CR 1995 Insulin action and the insulin signaling network. Endocrine Reviewes 16 117-142.

Cross DA, Alessi DR, Vandenheede JR, McDowell HE, Hundal HS \& Cohen P 1994 The inhibition of glycogen synthase kinase-3 by insulin or insulin-like growth factor 1 in the rat skeletal muscle cell line L6 is blocked by wortmannin, but not by rapamycin: evidence that wortmannin blocks activation of the mitogen-activated protein kinase pathway in L6 cells between Ras and Raf. Biochemical Foumal 303 21-26.

Cross DA, Alessi DR, Cohen P, Anduelkovich M \& Hemmings BA 1995 Inhibition of glycogen synthase kinase-3 by insulin mediated by protein kinase B. Nature 378 785-789.

Cui H, Meng Y \& Bulleit RF 1998 Inhibition of glycogen synthase kinase 3- $\beta$ activity regulates proliferation of cultured cerebellar granule cells. Brain Research. Developmental Brain Research 111 177-188.

De Groot PG, Willems C, Boers GHJ, Gonsalves MD, van Aken WG \& van Mourik JA 1983 Endothelial cell dysfunction in homocystinuria. European fournal of Investigation 13 405-410.

De Mattia G, Bravi MC, Laurenti O, Cassone-Faldetta M, Armiento A, Ferri C \& Balsano F 1998 Influence of reduced glutathione infusion on glucose metabolism in patients with non-insulin-dependent diabetes mellitus. Metabolism 47 993-997.

Diehl JA, Cheng M, Roussel MF \& Sherr CJ 1998 Glycogen synthase kinase- 3 beta regulates cyclin D1 proteolysis and subcellular localization. Genes and Development 12 3499-3511.

Dixon M, Agius L, Yeaman SJ \& Day CP 1999 Inhibition of rat hepatocyte proliferation by transforming growth factor beta and glucagons is associated with inhibition of ERK2 and p70 S6 kinase. Hepatology 29 1418-1424.

Ferrannini E, Haffner SM, Mitchel BD \& Stern MP 1991 Hyperinsulinemia: the key feature of a cardiovascular and metabolic syndrome. Diabetologica 34 416-422.

Guttormsen AB, Ueland PM, Nesthus I, Nygard O, Schneede J, Vollset SE \& Refsum H 1996 Determinants and vitamin responsiveness of intermediate hyperhomocysteinemia ( $>$ or $=40$ micromol/liter). The Hordaland Homocysteine Study. Fournal of Clinical Investigation 98 2174-2183.

Hansen LL, Ikeda Y, Olsen GS, Busch A \& Mosthaf L 1999 Insulin signaling is inhibited by micromolar concentrations of $\mathrm{H}_{2} \mathrm{O}_{2}$. Evidence for a role of $\mathrm{H}_{2} \mathrm{O}_{2}$ in tumor necrosis factor alpha-mediated insulin resistance. Fournal of Biological Chemistry 274 25078-25084.
Ikeda S, Kishida S, Yamamoto H, Murai H, Koyama S \& Kikuchi A 1998 Axin, a negative regulator of Wnt signaling pathway, forms a complex with GSK-3 beta and beta-catenin and promotes GSK-3 beta-dependent phosphorylation of beta-catenin. EMBO Fournal 17 1371-1384.

Jacques PF, Bostom AG, Williams RR, Ellison RC, Eckfeldt JH, Rosenberg IH, Sehub J \& Rozen R 1996 Relation between folate status, a common mutation in methylenetetrahydrofolate reductase, and plasma homocysteine concentrations. Circulation 93 7-9.

Jakubowski H 1997 Metabolism of homocysteine thiolactone in human cell cultures. Possible mechanism for pathological consequences of elevated homocysteine levels. Fournal of Biological Chemistry 272 1935-1942.

Jakubowski H, Zhang L, Barelequez A \& Aviv A 2000 Homocysteine thiolactone and protein homocysteineinylation in human endothelial cells implications for atherosclerosis. Circulation Research 87 45-51.

Kang SS \& Wong PW 1996 Genetic and nongenetic factors for moderate hyperhomocyst(e)inemia. Atherosclerosis 119 $135-138$.

Khamaisi M, Kavel O, Rosenstock M, Porat M, Yuli M, Kaiser N \& Rudich A 2000 Effect of glutathione synthesis on insulin action: in vivo and in vitro studies using buthioninesulfoximine. Biochemical Fournal 349 579-586.

Lipson KE, Pang L, Huber LJ, Chen H, Tsai JM, Hirth P, Gazit A, Levitzki A \& McMahon G 1998 Inhibition of platelet-derived growth factor and epidermal growth factor receptor signaling events after treatment of cells with specific synthetic inhibitors of tyrosine kinase phosphorylation. Fournal of Pharmacology and Experimental Therapeutics $285844-852$.

Loscalzo J 1996 The oxidant stress of hyperhomocyst(e)inemia. Journal of Clinical Investigation 98 5-7.

McCully KS 1993 Chemical pathology of homocysteine. Annals of Clinical and Laboratory Science 23 477-493.

McCully KS 1996 Homocysteine and vascular disease. Nature Medicine 2 386-389.

Manoukian AS \& Woodgett JR 2002 Role of glycogen synthase kinase-3 in cancer: regulation by Wnts and other signaling pathways. Advances in Cancer Research 84 203-229.

Meigs JB, Jacques PF, Selhub J, Singer DE, Nathan DM, Rifai N, D'Agostino RB Sr, Wilson PW \& Wilson PW; Framingham Offspring Study 2001 Fasting plasma homocysteine levels in the insulin resistance syndrome: the Framingham Offspring Study. Diabetes Care 24 1403-1410.

Myers MG \& White MF 1996 Insulin signal transduction and the IRS proteins. Annual Review of Pharmacology and Toxicology 36 615-658.

Najib S \& Sánchez-Margalet V 2001 Homocysteine thiolactone inhibits insulin signaling. Protective effect of glutathione. Fournal of Molecular Endocrinology 27 85-91.

Nakamura Y 1997 Cleaning up on $\beta$-catenin. Nature Medicine $\mathbf{3}$ 499-500.

Nourooz-Zadeh J, Rahimi A, Tajaddini-Sarmadi J, Tritschler H, Rosen P, Halliwell B \& Betteridge DJ 1997 Relationship between plasma measures of oxidative stress and metabolic control in NIDDM. Diabetologia 40 647-653.

Oron-Herman M, Rosenthal T \& Sela BA 2003 Hyperhomocysteinemia as a component of syndrome $\mathrm{X}$. Metabolism 52 1491-1495.

Orzechowski A, Lokociejewska M, Muras P \& Hocquette JF 2002 Preconditioning with millimolar concentrations of vitamin $\mathrm{C}$ or $\mathcal{N}$-acetylcysteine protects L6 muscle cells insulin-stimulated viability and DNA synthesis under oxidative stress. Life Sciences $\mathbf{7 1}$ 1793-1808.

Paolisso G \& Giuliano D 1996 Oxidative stress and insulin action: is there a relationship? Diabetologia 39 357-363.

Payne DM, Rossomando AJ, Martino P, Erickson AK, Her JH, Shabanowitz J, Hunt DF, Weber MJ \& Sturgill TW 1991 Identification of the regulatory phosphorylation sites in 
pp42/mitogen-activated protein kinase (MAP kinase). EMBO Fournal 10 885-892

Pham FH, Sugden PH \& Clerk A 2000 Regulation of protein kinase $\mathrm{B}$ and $4 \mathrm{E}-\mathrm{BP} 1$ by oxidative stress in cardiac myocytes. Circulation Research 86 1252-1258

Plyte SE, Hughes K, Nikolakaki K, Pulverer BJ \& Woodget JR 1992 Glycogen synthase kinase-3: functions in oncogenesis and development. Biochimica et Biophysica Acta 1114 147-162.

Pullen N, Dennis PB, Andjelkovic M, Dufner A, Kozma SC, Hemmings BA \& Thomas G 1998 Phosphorylation and activation of p70s6k by PDK1. Science 279 707-710.

Reaven GM 1993 Role of insulin resistance in human disease (syndrome X): an expanded definition. Annual Review Medicine 44 121-131.

Robinson K, Gupta A, Dennis VW, Arheart K, Chaudhary D, Green R, Vigo P, Mayer EL, Selhub J, Kutner M \& Jacobsen D 1996 Hyperhomocysteinemia confers an independent increased risk of atherosclerosis in end-stage renal disease and is closely linked to plasma folate and pyridoxine concentrations. Circulation $942743-2748$.

Rossig L, Badorff C, Holzmann Y, Zeiher AM \& Dimmeler S 2002 Glycogen synthase kinase-3 couples AKT-dependent signaling to the regulation of p21 Cipl degradation. Fournal of Biological Chemistry $2779684-9689$.

Rudich A, Kozlovsky N, Potashnik R \& Bashan N 1997 Oxidant stress reduces insulin responsiveness in 3T3-L1 adipocytes. American Fournal of Physiology 272 E935-E940.

Sánchez-Margalet V 2000 Stimulation of glycogen synthesis by insulin requires $\mathrm{S} 6$ kinase and phosphatidylinositol-3-kinase in HTC-IR cells. Fournal of Cellular Physiology 182 182-188.

Sánchez-Margalet V \& Najib S 1999 p68 Sam is a substrate of the insulin receptor and associates with the $\mathrm{SH} 2$ domains of $\mathrm{p} 85$ PI3K. FEBS Letters 455 307-310.

Sánchez-Margalet V, Goldfine ID, Vlahos C \& Sung CK 1994 Role of phosphatidylinositol-3-kinase in insulin receptor signaling: studies with inhibitor LY294002. Biochemical and Biophysical Research Communications 204 446-452.

Sánchez-Margalet V, Goldfine ID, Truitt K, Imboden J \& Sung CK 1995 Role of p85 subunit of phosphatidylinositol 3-kinase as an adaptor molecule linking the insulin receptor to insulin receptor substrate 1. Molecular Endocrinology 9 435-442.

Sánchez-Margalet V, Valle M, Ruz F, Gascón F, Mateo J \& Goberna R 2002 Elevated plasma total homocysteine levels in hyperinsulinemic obese subjects. Fournal of Nutritional Biochemistry 13 75-79.

Schachter M, Raziel A, Friedler S, Strassburger D, Bern O \& Ron-El R 2003 Insulin resistance in patients with polycystic ovary syndrome is associated with elevated plasma homocysteine. Human Reproduction 18 721-727.

Seghieri G, Breschi MC, Anichini R, De Bellis A, Alviggi L, Maida I \& Franconi F 2003 Serum homocysteine levels are increased in women with gestational diabetes mellitus. Metabolism $\mathbf{5 2}$ $720-723$.
Sehgal SN 1995 Rapamune (Sirolimus, rapamycin): an overview and mechanism of action. Therapeutic Drug Monitoring 17 660-665.

Skolnik EY, Batzer A, Li N, Lee CH, Lowenstein E, Mohammadi M, Margolis B, Schlessinger J 1993 The function of GRB2 in linking the insulin receptor to Ras signaling pathways. Science $\mathbf{2 6 0}$ 1953-1955.

Stamler JS, Osborne JA, Jaraki O, Rabbani LE, Mullins M, Singel D \& Loscalzo J 1993 Adverse vascular effects of homocysteine are modulated by endothelium-derived relaxing factor and related oxides of nitrogen. Fournal of Clinical Investigation 91 308-318.

Starkebaum G \& Harlan JM 1986 Endothelial cell injury due to copper-catalyzed hydrogen peroxide generation from homocysteine. Fournal of Clinical Investigation 77 1370-1376.

Sun XJ, Miralpeix M, Myers MG Jr, Glasheen EM, Backer JM, Kahn CR \& White MF 1992 Expression and function of IRS-1 in insulin signal transmission. Journal of Biological Chemistry $\mathbf{2 6 7}$ 22662-22672.

Sung CK, Sánchez-Margalet V \& Goldfine ID 1994 Role of p85 subunit of phosphatidylinositol-3-kinase as an adaptor molecule linking the insulin receptor, p62, and GTPase-activating protein. Fournal of Biological Chemistry 269 12503-12507.

Tirosh A, Potashnik R, Bashan N \& Rudich A 1999 Oxidative stress disrupts insulin-induced cellular redistribution of insulin receptor substrate-1 and phosphatidylinositol 3-kinase in 3T3-L1 adipocytes. A putative cellular mechanism for impaired protein kinase B activation and GLUT4 translocation. Fournal of Biological Chemistry 274 10595-10602.

Van Obberghen E, Baron V, Scimeca JC \& Kaliman P 1993 Insulin receptor: receptor activation and signal transduction. Advances in Second Messenger and Phosphoprotein Research 28 195-201.

Van Weeren PC, de Bruyn KMT, de Vries-Smits AMM, van Lint J \& Burgering BMTh 1998 Essential role for protein kinase B $(\mathrm{PKB})$ in insulin-induced glycogen synthase kinase 3 inactivation. Characterization of dominant-negative mutant of PKB. Fournal of Biological Chemistry 273 13150-13156.

Vinals F, Chambard JC \& Pouyssegur J 1999 p70 S6 kinase-mediated protein synthesis is a critical step for vascular endothelial cell proliferation. Journal of Biological Chemistry 274 26776-26782.

White MF, Shoelson SE, Kentmann N \& Kahn CR 1988 Cascade of tyrosine autophosphorylation in the $\beta$-subunit activates the insulin receptor. Fournal of Biological Chemistry 263 2969-2980.

Wittmann I \& Nagy J 1996 Are insulin resistance and atherosclerosis the consequences of oxidative stress? Diabetologia 39 1002-1003.

Xu Q Kenta T, Nakayama K, Furusu A, Moreno-Manzano V, Lucio-Cazana J, Ishikawa Y, Fine LG, Yao J \& Kitamura M 2004 Cellular defense against $\mathrm{H}_{2} \mathrm{O}_{2}$-induced apoptosis via MAP kinase-MKP-1 pathway. Free Radical Biology and Medicine 36 985-993.

Received 18 August 2004

Accepted 21 September 2004 